\author{
C.S. Christodoulou, R. Hand \& C. Charalambous
}

\title{
Tulipa akamasica (Liliaceae), a new endemic species from Cyprus
}

\begin{abstract}
Christodoulou, C.S., Hand, R. \& Charalambous, C.: Tulipa akamasica (Liliaceae), a new endemic species from Cyprus. — Fl. Medit. 24: 207-214. 2014. — ISSN: 1120-4052 printed, 2240-4538 online.

Tulipa akamasica (Liliaceae) is described as new to science. Its occurrence is restricted to a small area on serpentine substrate in the Akamas peninsula in the western part of Cyprus. The diploid plant belongs to the controversial $T$. orphanidea species group, but differs from its segregates by the delicateness of most organs.
\end{abstract}

Key words: Akamas peninsula, Endemism, Red Data Book, Tulipa orphanidea group.

\section{Introduction}

According to Zonneveld \& de Groot (2012) the genus Tulipa L. (Liliaceae) has at least 87 species, although new taxa with restricted ranges are regularly added to the list (see, e.g., recent reports by Shuka \& al. 2012; Zonneveld \& de Groot 2012). However, the total number of taxa is much disputed depending on the species concept (see Zonneveld 2009; Fay \& Christenhusz in Everett 2013: 78 species). "Despite the existence of a large body of literature on Tulipa, its taxonomy is generally regarded as difficult, as stated in every taxonomic treatment" (Zonneveld \& de Groot 2012). We need add nothing more to this statement. The state of knowledge has been summarized in the latter paper, as well as in the biosystematic studies by van Raamsdonk \& de Vries $(1992,1995)$ and the monographs by Hall (1940), Botschantzeva (1982), Wilford (2006) and Everett (2013).

Two species of tulips are known to occur in Cyprus, Tulipa agenensis DC., which is classified as a naturalized non-invasive taxon on the island, and T. cypria Stapf, a rare endemic (Hand $\&$ al. 2014). Their relationships are discussed by Meikle (1985) but their phylogeny is far from clarified. A third tulip was discovered by Christos Charalambous in 1991 in the Akamas peninsula in western Cyprus. Preliminary studies led to the conclusion that it belongs to the polymorphic T. orphanidea group but to an undescribed taxon (Wilford in Tsintides \& al. 2007). Because of its rarity it has been included in the "Red Data Book of the Flora of Cyprus" as unnamed taxon and classified as Critically Endangered (Tsintides \& al. 2007). Since that time, however, more material has been studied in the field and in the herbarium. Our studies have led to the conclusion that the Akamas tulip represents a species new to science. 


\section{Material and methods}

Results are based on all-year round studies of the only known population in the field, on gatherings conserved in the herbaria at B and CYP, and plants grown in the greenhouses at B.

Taxonomy and nomenclature of taxa occurring in Cyprus follow Hand \& al. (2014).

\section{Results}

Tulipa akamasica Christodoulou, Hand \& Charalambous, spec. nova

Holotypus: Cyprus, Neo Chorio, SSE Smigies picnic site, phrygana on serpentine, alt. 370 $\mathrm{m}, 29.03 .2012$, leg. R. Hand $5945 \&$ C. Charalambous (B; iso- B).

Additional specimen from the same site: 22.3.2007, leg. C. S. Christodoulou (CYP 5196).

Stature: tulip erect in all stages; height 9-25(-30) $\mathrm{cm}$.

Bulb: globose-elongated, 17-20(-25) $\times 12-18 \mathrm{~mm}$; not stoloniferous; tunics outside dark brown to blackish-brown, glabrous, inside lighter brown, glabrous with a ring of hairs around basal plate and a villose stripe at the neck; hairs brownish, mostly $2-3 \mathrm{~mm}$ long.

Stem: erect, pubescent with short whitish hairs, single flowered, 2-2.5 $\mathrm{mm}$ in diameter (widest subterranean part), green in the lower part, tinged reddish-brown in the upper half, underground part c. $6 \mathrm{~cm}$ long, whitish.

Leaves: 3-7, canaliculate in young state, later flattish, green, slightly glaucous on the upper side, produced at ground level, glabrous and without cilia, the lower 130-305 × (3-)4$12(-16) \mathrm{mm}$, the upper ones shorter, mostly 2-3 mm wide. Often exceeding the flower or a bit shorter, acute to acuminate.

Flower: solitary, (66-)70-75 mm diam., opening to a loose star, glabrous, bud straight, tepals bright red, inside with a basal black, mostly very irregularly dentate blotch (c. 10$20 \%$ of length), followed by a c. $1.5 \mathrm{~mm}$ wide yellow band, outside red, lower third at anthesis often greenish.

Perianth segments: slightly unequal.

Outer tepals: obovate-clavate, attenuate at base, acute, sometimes obtuse, 31-41 × 10-15 mm. Inner tepals: obovate, attenuate at base, obtuse to more or less acute, 33-38(-42) $\times$ (13-)17-19(-20) $\mathrm{mm}$.

Stamens: longer than the ovary, unequal. Filaments purplish, whitish at base, hairy and dilated at base, 6-6.5 mm long. Anthers 3.5-4 mm long at anthesis, purplish, later brown and often lengthening up to $8-10 \mathrm{~mm}$, pollen yellow.

Ovary: $8 \times 3.5 \mathrm{~mm}$, subsessile, glabrous, yellow, stigma sessile, no. of stigmas 3 , yellow-white. Young capsule: oblanceolate, bluntly pointed, $10 \mathrm{~mm}$ long; ripe capsule and seeds not seen.

Illustrations: Fig. 1, further photos can be found at Hand \& al. 2014.

Chromosome number: diploid, $2 n=2 \mathrm{x}=24$ (Fig. 2).

Phenology: flowering March-April, fruiting in May. 

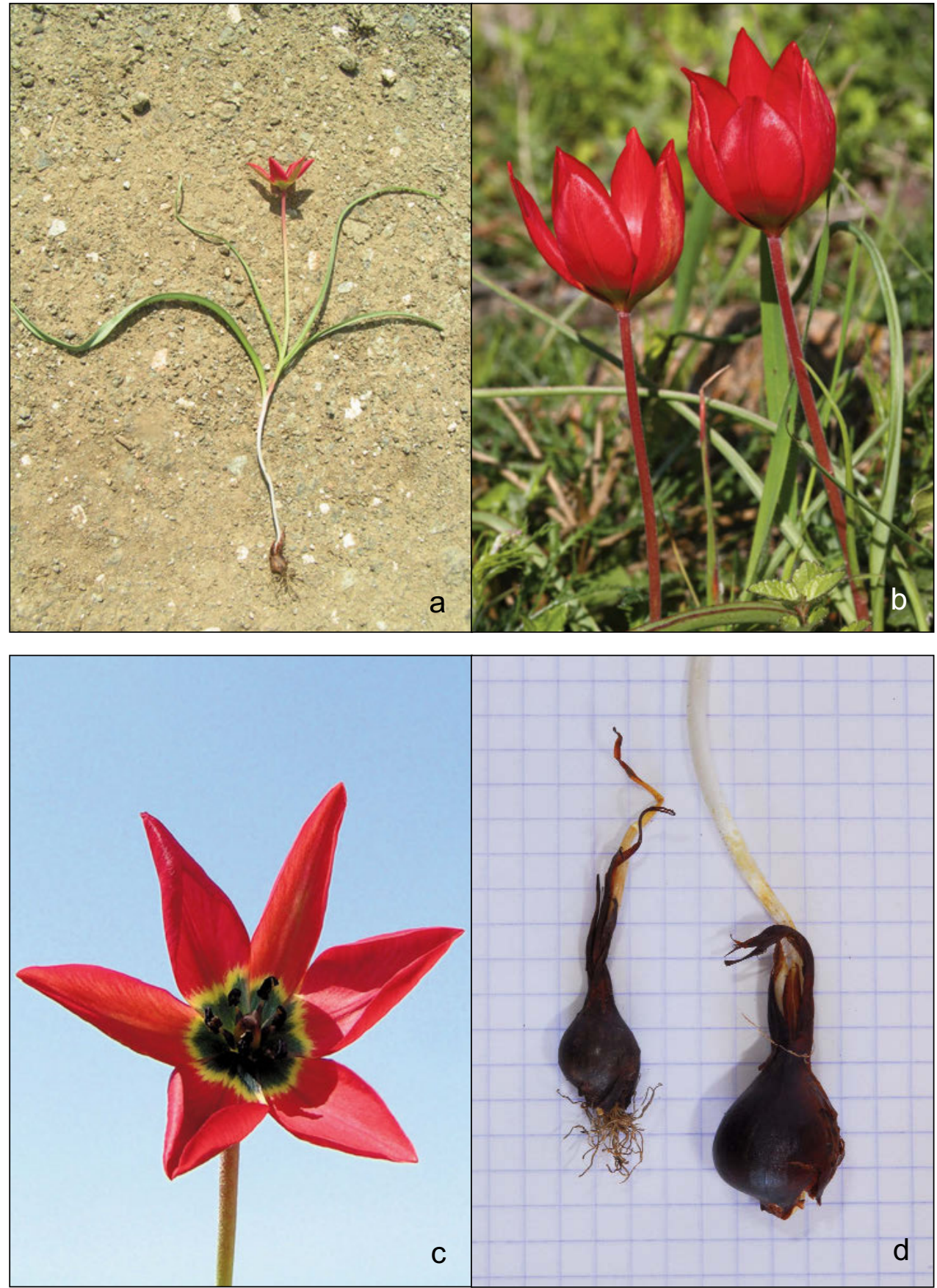

Fig. 1. a. Habit of a complete plant; photo: T. Papachristophorou, 21.03.2007; b. Opening flowers; photo: C. Makris, 26.03.2007; c. Open flower; photo: T. Papachristophorou, 21.03.2007; d. Bulbs with dark brown tunics; scale: $5 \mathrm{~mm}$ grid; photo: C. S. Christodoulou, 23.04.2013. 


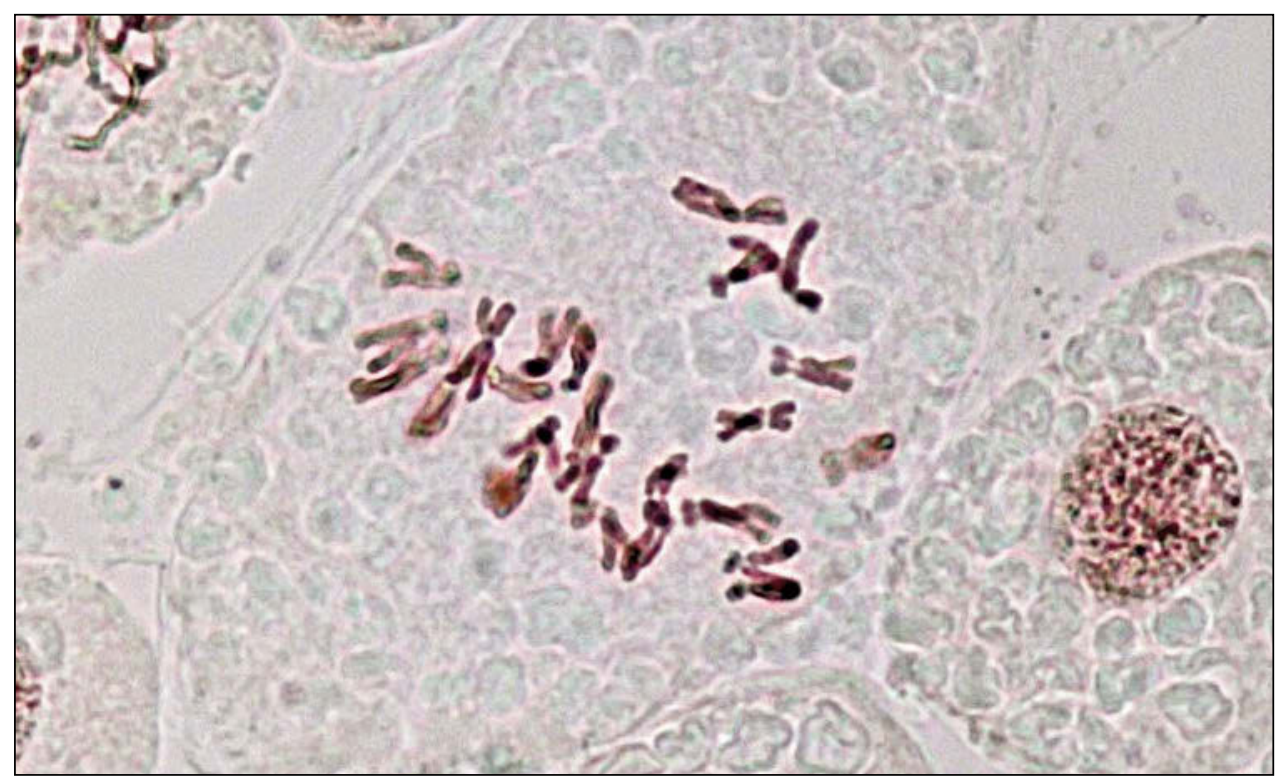

Fig. 2. Metaphase of root tip mitose, showing $2 n=24$ chromosomes; photo: M. Lüchow \& R. Hand.

\section{Distribution and ecology}

T. akamasica is known to occur only in one site in the Akamas peninsula in the westernmost part of Cyprus. The whole population is found on a slope consisting of Upper Cretaceous serpentines; limestones are to be found nearby, a situation quite common in the geological mosaic of the area. The altitude is about $370 \mathrm{~m}$ above sea level. The slope is colonized by relatively dense phrygana (with scattered low shrubs) in which, e.g., the following taxa are to be found: Alyssum akamasicum B. L. Burtt, Arisarum vulgare Targ. Tozz., Asphodelus ramosus L., Calycotome villosa (Poir.) Link, Cistus monspeliensis L., Drimia aphylla (Forssk.) J. C. Manning \& Goldblatt, Euphorbia dimorphocaulon P.H. Davis, Lithodora hispidula subsp. versicolor Meikle, Olea europaea L., Prasium majus L., Scaligeria alziarii Hand \& al., Senecio vulgaris L. The endemic Alyssum akamasicum is a serpentinophilous species whereas the endemic Scaligeria alziarii prefers serpentine outcrops in this part of Cyprus. Soil layer is relatively thick compared to neighbouring serpentine areas where bare rocks often dominate.

\section{Conservation}

As already described by Papachristophorou (in Tsintides \& al. 2007), the species is known from only one location. It has been classified as "Critically Endangered" (CR; IUCN criteria B1ab(iii,v)+2ab(iii,v)). Due to uncontrolled overgrazing by goats, a part of its population has been fenced since the 1990 s (c. $300 \mathrm{~m}^{2}$ ). The population outside the 
fenced area has been nearly destroyed and only few plants can survive and produce flowers. Actually, the world population comprises only about 200 plants. Further protection measures are urgently needed. We recommend the expansion of fencing to cover an area of about 1 ha. Grazing should be totally banned in the period from late winter to June. Subsequently, a moderate, controlled grazing would be helpful to prevent the vegetation becoming a very dense phrygana or maquis.

Efforts to establish ex situ conservation of the species (Athalassa Cyprus; Botanical Garden Berlin-Dahlem) have not been entirely successful. So far, no flowers have been produced ex situ, although cultivation continues. In the last years, no ripe capsules could be found in the field. The fertility of the population seems to be low and fruiting has been observed only very irregularly.

Because of its rarity, we refrain from publishing the exact locality and exact coordinates.

\section{Discussion}

T. akamasica resembles most closely T. orphanidea s. 1 . from Greece and Turkey but is distinguishable from it by its following combination of characters: Relatively delicate, non-stoloniferous bulb (up to $18 \mathrm{~mm}$ in diameter vs. (10-)15-30 $\mathrm{mm}$ in T. orphanidea s. 1.) with dark to blackish-brown tunic, delicate stem (2-2.5 $\mathrm{mm}$ in diameter) and lower leaves (mostly 4-12 mm wide vs. (8-)10-20 $\mathrm{mm}$ in T. orphanidea s. 1.), bright red tepals, inside with a basal black, very irregularly dentate blotch which is bordered by a c. $1.5 \mathrm{~mm}$ wide yellow band, short purplish filaments (6-6.5 mm vs. 7-12 mm in T. orphanidea $\mathrm{s}$. 1.) with hairy, dilated base, small purplish anthers, 3.5-4 mm long at anthesis (at least $5.5 \mathrm{~mm}$ in $T$. orphanidea s. 1.), yellow pollen (Table 1).

Our results confirm earlier suspicions that the Cypriot taxon is morphologically very close to T. orphanidea. All characters speak in favour of placing it into Tulipa subgen. Eriostemones sect. Sylvestres (Baker) Baker in the sense of Zonneveld (2009) and Veldkamp \& Zonneveld (2012) and sect. Saxatiles (Baker) Baker subsect. Orphanidetes Eker \& Babaç in the sense of Eker \& al. (2014) respectively. For the time being, Fay \& Christenhusz (in Everett 2013) recommend accepting subgenera only, holding off on sections and subsections because this would be premature. The same authors believe that "some species complexes still need further revision" and the T. orphanidea group certainly belongs in this category. It is known to occur in the wider Aegean Sea region comprising, e.g. Thrace, S. Greece, Crete and the westernmost part of Anatolia eastwards to the Alanya region (Eker \& al. 2014; Marais 1984).

Despite the popularity of tulips, data on the phylogeny of the group is surprisingly scarce. According to Zonneveld (2009) T. orphanidea could be an old hybrid of T. hageri Heldr. and T. sylvestris L., a theory earlier postulated by Hall (1940). Recently, Fay \& Christenhusz (in Everett 2013) have greatly elucidated the infrageneric structure of the genus but the complicated taxa groups are far from being clarified. The phylogenetic position of the new taxon from Cyprus will be dealt with in a future paper.

Unfortunately, the knowledge of the T. orphanidea group is fragmentary - not to say anecdotic. There is no systematic revision of it based on field studies throughout its entire area and based on common garden experiments. Such a synthesis of mor- 


\begin{tabular}{|c|c|c|c|c|c|c|c|c|c|c|}
\hline 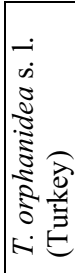 & 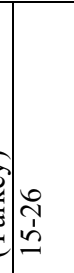 & 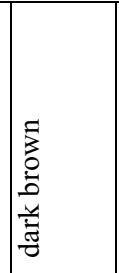 & in & 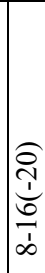 & 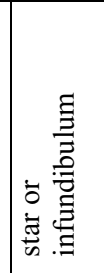 & 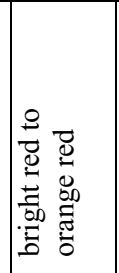 & $\begin{array}{l}\vec{\gamma} \\
\hat{\alpha} \\
x \\
\infty \\
\infty \\
\hat{n} \\
\tilde{n}\end{array}$ & 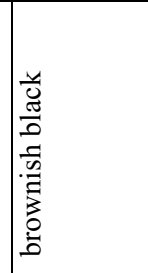 & $\begin{array}{l}\bar{z} \\
\bar{z} \\
\bar{z} \\
\bar{z}\end{array}$ & 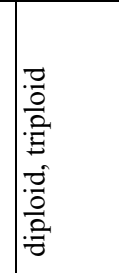 \\
\hline 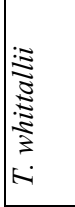 & 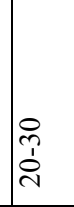 & 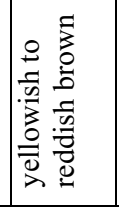 & pi & సి & 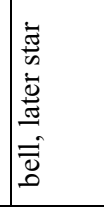 & 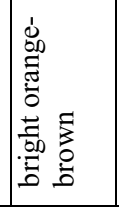 & 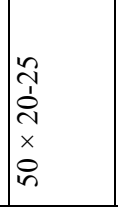 & 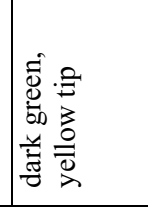 & 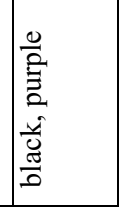 & 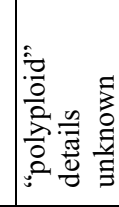 \\
\hline 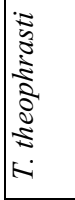 & $\approx$ & $\begin{array}{l}5 \\
0 \\
0 \\
0 \\
0 \\
0 \\
.00 \\
=\end{array}$ & $\approx$ & a. & a. & 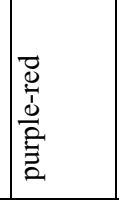 & $\begin{array}{l}a \\
\dot{x} \\
\dot{q}\end{array}$ & $\begin{array}{l}\frac{4}{0} \\
\frac{\pi}{0}\end{array}$ & $\frac{\frac{4}{0}}{\frac{\pi}{0}}$ & r. \\
\hline 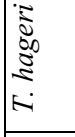 & 离 & 竘 & $\cong$ & $\cong$ & $\bar{\Xi}$ & 总 & 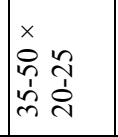 & 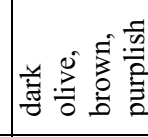 & 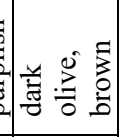 & $=$ \\
\hline 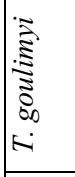 & ঙ̊. & 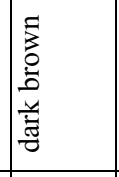 & $\approx$ & ¿ & 志 & 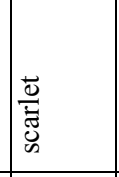 & $\begin{array}{l}0 \\
\stackrel{0}{x} \\
\infty \\
m \\
\end{array}$ & 总 & 总 & :0 \\
\hline 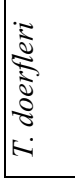 & $\cong$ & 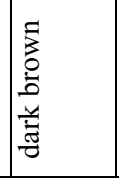 & in & 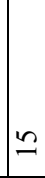 & 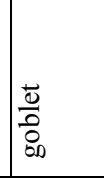 & 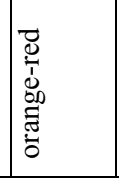 & 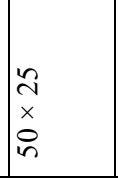 & 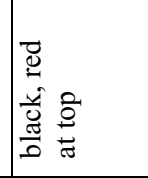 & $\mid \begin{array}{l}\frac{\ddot{m}}{0} \\
\frac{\pi}{0}\end{array}$ & 吾 \\
\hline 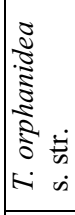 & 2 & 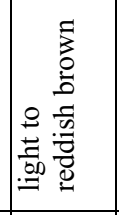 & iิ & 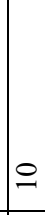 & 莺 & 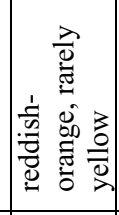 & 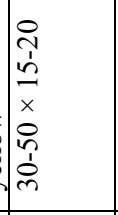 & 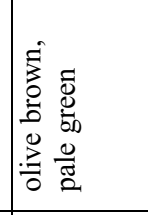 & 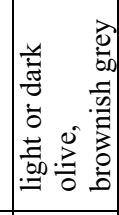 & : \\
\hline 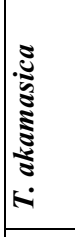 & $\frac{\infty}{\beth}$ & 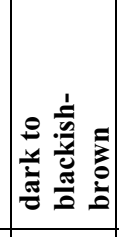 & 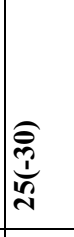 & 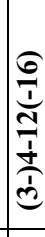 & 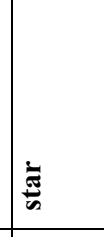 & 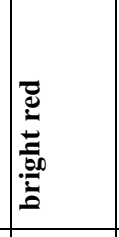 & 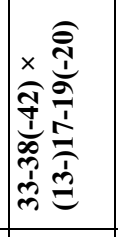 & 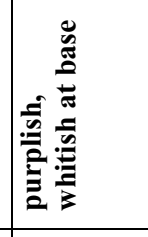 & 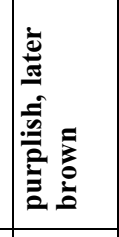 & : \\
\hline & 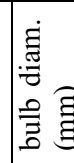 & 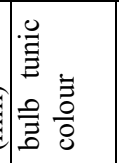 & 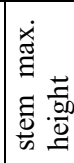 & & 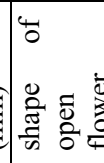 & 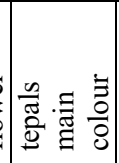 & 这 & 结总 & 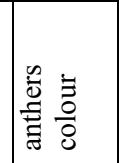 & $\frac{\frac{\pi}{0}}{\frac{0}{2}}$ \\
\hline
\end{tabular}


phology, karyology and genetics of the species group is urgently required. Most publications are based on material from parts of the distribution range and focussing on certain aspects such as karyology, anatomy or morphometrics (Baytop \& Mathew 1984; Marais 1984; Başak \& Özhatay 1997; Soykan \& Meriç 2012; Eker \& al. 2014). Some authors advocate a broad species concept that would include taxa such as $T$. bithynica Griseb. ex Baker, T. hageri Heldr., T. thracica Davidov, T. hellespontica Degenin, T. hayatii O. Schwarz, and T. whittallii A. D. Hall. In the recently published revision of Turkish tulips (Eker \& al. 2014) T. orphanidea is treated in a wide sense unfortunately no complete synonymy is presented. Everett (2013) recommends treating T. orphanidea in a wide sense as well, but she reveals her indecision by giving full descriptions of the synonymized taxa, most of them listed above. Some authors advocate treating certain segregates as good species and others as subspecies of orphanidea (e.g., Zonneveld 2009). On the other hand, Dimopoulos \& al. (2013) accept the Greek segregate taxa at species level. However, the diploid T. akamasica probably evolved in isolation on the island of Cyprus. It can be differentiated even from tiny specimens of $T$. orphanidea s. 1. by a combination of characters such that we advocate species rank. All of the more or less disputed segregates from Greece and Turkey combine characteristics that do not fit the Cypriot plant.

Cyprus is one of the hotspots of Mediterranean endemism. The evolution of endemics, closely related to taxa from the neighbouring mainland is a well-known phenomenon. Hyacinthella millingenii (Post) Feinbrun, Scilla morrisii Meikle and Ornithogalum chionophilum Holmboe are such taxa, to name but a few examples of bulbous species.

\section{Acknowledgements}

The authors would like to thank Monika Lüchow (B) for assistance in laboratory work, Michael Meyer and his team of gardeners (B) for the cultivation of the plants, Christodoulos Makris (Lemesos) and Takis Papachristophorou (Lefkosia) for providing photographs, and Kathleen Stephanides (Lefkosia) who kindly improved the manuscript linguistically.

\section{References}

Başak, N. \& Özhatay, N. 1997: Cytotaxonomic notes on the Tulipa species (Liliaceae) of European Turkey. - Bocconea 5: 727-731.

Baytop, T. \& Mathew, B. 1984: The bulbous plants of Turkey. - London.

Botschantzeva, Z.P. 1982: Tulips. Taxonomy, morphology, cytology, phytogeography and physiology. - Rotterdam.

Dimopoulos, P., Raus, T., Bergmeier, E., Constantinidis, T., Iatrou, G., Kokkini, S., Strid, A. \& Tzanoudakis, D. 2013: Vascular plants of Greece. - Englera 31: 1-372.

Eker, I., Babaç, M.T. \& Koyuncu, M. 2014: Revision of the genus Tulipa L. (Liliaceae) in Turkey. Phytotaxa 157: 1-112. doi: 10.11646/phytotaxa.157.1.1

Everett, D. 2013: The genus Tulipa. - Kew.

Hall, A.D. 1940: The genus Tulipa. - London.

Hand, R., Hadjikyriakou, G.N. \& Christodoulou, C.S. (ed.) 2014 (continuously updated): Flora of Cyprus - a dynamic checklist. - Published at http://www.flora-of-cyprus.eu/ [accessed 31.07.2014]. 
Marais, W. 1984: Tulipa L. - Pp. 302-311 in: Davis, P.H. (ed.), Flora of Turkey and the East Aegean Islands, 8. - Edinburgh.

Shuka, L., Tan, K. \& Krasniqi, E. 2012: Tulipa kosovarica (Liliaceae), a new species of tulip from Kosovo. - Phytotaxa 62: 1-9.

Soykan, A. \& Meriç, Ç. 2012: Morphological and anatomical studies of Tulipa orphanidea (Liliaceae). Phytol. Balcan. 18: 43-48.

Tsintides, T., Christodoulou, C.S., Delipetrou, P. \& Georghiou, K. (ed.) 2007: The Red Data Book of the flora of Cyprus. - Lefkosia.

van Raamsdonk, L.W.D. \& de Vries, T. 1992: Biosystematic studies in Tulipa sect. Eriostemones (Liliaceae). - Pl. Syst. Evol. 179: 27-41.

— \& - 1995: Species relationships and taxonomy in Tulipa subg. Tulipa (Liliaceae). - P1. Syst. Evol. 195: 13-44.

Veldkamp, J.F. \& Zonneveld, B.J.M. 2012: The infrageneric nomenclature of Tulipa (Liliaceae). Pl. Syst. Evol. 298: 87-92. doi: 10.1007/s00606-011-0525-0

Wilford, R. 2006: Tulips. Species and hybrids for the gardener. - Portland.

Zonneveld, B.J.M. 2009: The systematic value of nuclear genome size for "all" species of Tulipa L. (Liliaceae). - Pl. Syst. Evol. 281: 217-245. doi: 10.1007/s00606-009-0203-7

— \& de Groot, J.J. 2012: Tulipa kolbintsevii Zonn., a new species from Eastern Kazakhstan. - Pl. Syst. Evol. 298: 1293-1296. doi: 10.1007/s00606-012-0635-3

Addresses of the authors:

Charalambos S. Christodoulou ${ }^{1}$, Ralf Hand ${ }^{2} \&$ Christos Charalambous ${ }^{3}$,

${ }^{1}$ Department of Forests, 26 Louki Akrita, CY-1414 Nicosia, Cyprus; E-mail: floracy@primehome.com

${ }^{2}$ Botanic Garden and Botanical Museum Berlin-Dahlem, Freie Universität Berlin, Königin-Luise-Str. 6-8, D-14195 Berlin, Germany; E-mail: r.hand@bgbm.org

${ }^{3}$ Andrea Ioannou 8, CY-8047 Ktima Paphos, Cyprus; E-mail: ecologia@cytanet.com.cy 